\title{
Use of Dry Milk Protein Concentrate in Pizza Cheese Manufactured by Culture or Direct Acidification
}

\author{
Shakeel-Ur-Rehman, N. Y. Farkye, and B. Yim \\ Dairy Products Technology Center, \\ California Polytechnic State University, \\ San Luis Obispo 93407
}

\section{ABSTRACT}

Milk protein concentrate (MPC) contains high concentrations of casein and calcium and low concentrations of lactose. Enrichment of cheese milk with MPC should, therefore, enhance yields and improve quality. The objectives of this study were: 1 ) to compare pizza cheese made by culture acidification using standardized whole milk (WM) plus skim milk (SM) versus WM plus MPC; and 2) compare cheese made using WM + MPC by culture acidification to that made by direct acidification. The experimental design is as follows: vat $1=\mathrm{WM}+\mathrm{SM}+$ culture (commercial thermophilic lactic acid bacteria), vat $2=\mathrm{WM}+\mathrm{MPC}+$ culture, and vat $3=\mathrm{WM}+\mathrm{MPC}+$ direct acid ( $2 \%$ citric acid). Each cheese milk was standardized to a protein-to-fat ratio of $\sim 1.4$. The experiment was repeated three times. Yield and composition of cheeses were determined by standard methods, whereas the proteolysis was assessed by urea polyacrylamide gel electrophoresis (PAGE) and water-soluble $\mathrm{N}$ contents. Meltability of the cheeses was determined during 1 mo of storage, in addition to pizza making. The addition of MPC improved the yields from $10.34 \pm 0.57 \%$ in vat 1 cheese to $14.50 \pm 0.84 \%$ and $16.65 \pm 2.23 \%$, respectively, in vats 2 and 3 and cheeses. The percentage of fat and protein recoveries showed insignificant differences between the treatments, but TS recoveries were in the order, vat $2>$ vat $3>$ vat 1 . Most of the compositional parameters were significantly affected by the different treatments. Vat 2 cheese had the highest calcium and lowest lactose contencentrations. Vat 3 cheese had the best meltability. Vat 1 cheese initially had better meltability than vat 2 cheese; however, the difference became insignificant after $28 \mathrm{~d}$ of storage at $4^{\circ} \mathrm{C}$. Vat 3 cheese had the softest texture and produced largesized blisters when baked on pizza. The lowest and highest levels of proteolysis were found in vats 2 and 3 cheeses, respectively. The study demonstrates the

Received February 28, 2003

Accepted May 5, 2003.

Corresponding author: N. Y. Farkye; e-mail: nfarkye@calpoly.edu. use of MPC in pizza cheese manufacture with improved yield both by culture acidification as well as direct acidification.

(Key words: pizza cheese, milk protein concentrate, acidification)

Abbreviation key: MPC = milk protein concentrate, NFDM = nonfat dry milk, SM = skim milk, $\mathbf{W M}=$ whole milk.

\section{INTRODUCTION}

Mozzarella cheese, a pasta-filata variety, constituted $\sim 32.4 \%$ of the total cheese produced in the United States in 2001 (USDA, 2002). About 70\% of the Mozzarella cheese produced in the United States is used in pizza manufacture and falls into the low-moisture, part-skim category, with a fat content of 30 to $45 \%$ on DM basis and moisture content of 45 to $52 \%$ (McMahon, et al., 1993). Mozzarella-type cheese not manufactured by the pasta-filata process is called pizza cheese. There has been a sharp increase in the consumption of pizza worldwide, resulting in high demand for Mozzarella or pizza cheese. Pizza cheese is an irreplaceable cheese for pizza because of its strechability-the ability to form fibers or strings when hot.

To meet the moisture and fat requirements for lowmoisture, part-skim Mozzarella, cheese milk is standardized to a desired protein-to-fat ratio of 1.4:1. This is equivalent to a casein-to-fat ratio of $\sim 1.2: 1$, assuming casein represents $78 \%$ of the total protein in milk. The casein-to-fat ratio in normal bovine milk is between 0.64 to 0.72 , depending on breed of cow. To increase the casein-to-fat ratio in cheese milk, nonfat dry milk (NFDM), condensed skim, or membrane concentrated skim milk are used in standardization of milk. Alternatively, some of the fat in whole milk can be removed as cream. The standardization of cheese milk by addition of solids in the form of NFDM, condensed skim does not only increase cheese yield, but also reduces the amount of whey. Demott (1982) manufactured Mozzarella-type cheese from NFDM by direct acidification method. The source of solids for cheese milk present some disadvantages. For example, the 
addition of NFDM or condensed skim may result undesirable fermentations during manufacture or extensive browning when cheese is used as a pizza topping due to its high lactose content compared with high solids ultrafiltration and diafiltered retentate.

Milk protein concentrate (MPC), manufactured by spray drying of ultrafiltration retentate, has high concentrations of casein and calcium and low concentrations of lactose compared to NFDM. Enrichment of whole milk with MPC should, therefore, enhance yields and improve quality of cheese. Milk protein concentrate has been used in France and Denmark for the manufacture of Camembert, Feta, and Ricotta type cheeses (Pederson and Ottosen, 1992). The use of liquid and dry MPC in the manufacture of reduced-fat Cheddar cheeses has been reported (Shakeel-Ur-Rehman et al., 2003a, 2003b).

The objectives of this study were 1) to compare pizza cheese made by culture acidification using whole milk (WM) standardized with skim milk versus WM standardized with MPC; 2) compare cheese made with WM plus MPC by culture acidification to that made by direct acidification.

\section{MATERIALS AND METHODS}

\section{Cheese Manufacture}

Three vats of pizza cheese were manufactured on three occasions (three trials). Vat 1 contained standardized milk consisting of $21.8 \mathrm{~kg}$ of skim milk (SM) plus $103.2 \mathrm{~kg}$ of $\mathrm{WM}$ and commercial thermophilic lactic acid bacteria. Standardized milk for vats 2 and 3 contained WM and MPC. Target protein-to-fat ratio in the standardized milk was 1.4. Milk protein concentrate was obtained from Main Street Ingredients (La Crosse, WI). It contained $63.5 \%$ protein, $20.9 \%$ lactose, $5 \%$ moisture, $3.1 \%$ fat, and $7.5 \%$ ash. Milk protein concentrate $(4.925 \mathrm{~kg})$ and raw WM $(245 \mathrm{~kg})$ were mixed in a tank before pasteurization. Each lot of standardized milk $(\sim 125 \mathrm{~kg})$ was pasteurized at $72^{\circ} \mathrm{C} \times$ 16 s using a universal pilot plant (PMS, Processing Machine and Supply Co., Philadelphia, PA) with a capacity to process $1.9 \mathrm{~L}$ of milk per minute. The pasteurized milk was cooled to $36^{\circ} \mathrm{C}$ for vats 1 and 2 and $4^{\circ} \mathrm{C}$ for vat 3 . The beginning and end of each standardized milk $(\sim 10 \mathrm{~kg})$ exiting the heat exchanger was discarded, and $100 \mathrm{~kg}$ was poured in the vat for cheesemaking. The percentage of TS in vats 1,2 , and 3 were 11.42, 13.44, and 13.44, respectively. Frozen direct-vat set thermophillic starter culture obtained from Chr. Hansen's Inc., (Milwaukee, WI) was added to vats 1 or 2 at the rate of $6.6 \mathrm{~g}$ (3.3 g of Lactobacillus bulgaricus, ssp. bulgaricus LB12, and $3.3 \mathrm{~g}$ of Streptococcus thermophilus, STC5) per $100 \mathrm{~kg}$ of milk at $36^{\circ} \mathrm{C}$. After the addition of starter, the contents of vats 1 and 2 were held for $45 \mathrm{~min}$ to ripen. Then, rennet (Chymax, Chr Hansen's Inc.) was added ( $7 \mathrm{ml} / 100 \mathrm{~kg}$ of milk) to each vat, followed by 2 min of stirring. The vat contents were held undisturbed until a firm coagulum formed ( $30 \mathrm{~min})$. The coagulum was cut with 1-cm horizontal and vertical curd wire knives. The cut curds were healed for 2 to $3 \mathrm{~min}$ before slow stirring for $10 \mathrm{~min}$. The curds were cooked to $46^{\circ} \mathrm{C}$ over $30 \mathrm{~min}$ with gentle stirring until the curd $\mathrm{pH}$ (measured by inserting $\mathrm{pH}$ electrode directly into a sample of squeezed curd) reached 6.2 in 30 to $40 \mathrm{~min}$. The curds were allowed to settle in whey and the curd/whey mixture held under quiescent conditions until the $\mathrm{pH}$ reached to 5.3. The whey was drained followed by stretching of curds in hot water $\left(82.3^{\circ} \mathrm{C}\right)$. It took $\sim 2$ to $3 \mathrm{~h}$ from cutting to stretching. The stretched molten cheese was placed in a 2.5 $\mathrm{kg}$ hoop to form a loaf. After removal from the hoop, the cheese was placed in cold $\left(3^{\circ} \mathrm{C}\right)$ brine $(20 \%$ $\mathrm{NaCl}+0.01 \% \mathrm{CaCl}_{2}, \mathrm{pH} 4.6$ ) for $12 \mathrm{~h}$. The cheese blocks were taken out from the brine and vacuum packaged in Cryovac bags.

Vat 3 milk previously cooled to $4^{\circ} \mathrm{C}$ was directly acidified with $2 \%$ cold $\left(3^{\circ} \mathrm{C}\right)$ citric acid to a $\mathrm{pH}$ of 5.6. Citric acid was selected because it is a strong chelator of calcium. After the addition of citric acid, the temperature of milk in the vat was increased to $31^{\circ} \mathrm{C}$ followed by the addition of chymosin (Chymax, Chr. Hansen's Laboratory, Milwaukee, WI) at the rate of $5 \mathrm{ml} / 100 \mathrm{~kg}$ of milk. It took $\sim 5$ min for coagulum formation. The curd was cut with horizontal wire knives like vats 1 and 2 . The cut curd was healed for $5 \mathrm{~min}$ and then the temperature of the contents of the vat was increased to $36^{\circ} \mathrm{C}$ followed by stirring for $5 \mathrm{~min}$. The whey was drained in $30 \mathrm{~min}$. The curds were stretched, brine salted, and vacuum packaged as was done for cheese obtained from vats 1 and 2 . All the cheeses were transferred to a storage room at $4^{\circ} \mathrm{C}$ and kept for $4 \mathrm{wk}$.

\section{Yield}

The yield of cheese was determined by weighing the cheese obtained in each vat after removal from the brine, and expressed as a percentage of the milk weight in the respective vat.

\section{Compositional Analyses}

Fat in milk and cheese was analyzed by the Babcock method (Marshall, 1992). Total solids in milk and moisture in cheese were determined by the microwave oven method (CEM AVC 80 microwave oven, CEM Corporation, Matthews, NC) (Marshall, 1992). Protein (total $\mathrm{N} \times 6.38$ ) was determined by the Kjeldahl 
method, salt by titration using the Corning 926 Chloride analyzer (Corning, Medfield, MA), and lactose and $\beta$-galactose by enzymatic methods (Boehringer-Mannheim Biochemicals, Mannheim, Germany). Cheese $\mathrm{pH}$ was determined using a glass electrode on a slurry prepared by thoroughly blending $10 \mathrm{~g}$ of grated cheese with $10 \mathrm{ml}$ of deionized water using a mortar and pestle. Calcium in the cheese was determined by AOAC method 991.25 (AOAC, 2002) by using PerkinElmer 3030B Atomic Absorption spectrophotometer (Norwalk, CT).

\section{Functional Properties}

Meltability (cheese flow) of the cheeses was measured by using the method of Olson and Price (1958) on 15-g sample cut out of a block with a small circular cutter. The sample was placed in a cylindrical glass tube (23.3-cm long $\times 3.0-\mathrm{cm}$ i.d.), open on both ends. The end in which the sample was placed was closed by rubber cork. The tube containing the cheese sample was placed on a stainless steel rack having the provision of holding the tube in the horizontal or at a $45^{\circ}$ inclined position. The rack was set at the inclined position in an incubator at $32^{\circ} \mathrm{C}$ for $1 \mathrm{~h}$ to temper the cheese, after which the rack was set on the horizontal position in an oven at $110^{\circ} \mathrm{C}$ for $1 \mathrm{~h}$. The meltability of the sample was measured as the distance $(\mathrm{cm})$ that the cheese had flowed from the original position after the tempering period.

The baking property of the cheese was determined by evenly distributing cheese ( $200 \mathrm{~g}$ ) over a commercial pizza crust (27.5 cm diameter) containing pizza sauce $(90 \mathrm{~g})$ followed by baking in continuous Impinger oven (model 1301 Lincoln, Wayne, IN) at $232^{\circ} \mathrm{C}$ for 3.25 $\mathrm{min}$. The conveyor speed was $0.33 \mathrm{rpm}$.

\section{Hardness}

A modified method of Bhaskaracharya and Shah (2000) was used to assess hardness of 7-d-old cheeses. The cheese blocks were tempered $25^{\circ} \mathrm{C}$ for $1 \mathrm{~h}$ and triplicate cylindrical samples $(2.5 \mathrm{~cm}$ height $\times 3.0 \mathrm{~cm}$ diameter) from each block were drawn with a cheese plug. Cheese hardness, defined as the force required to compress 50 or $70 \%$ height of sample, was determined by a TAXT2 Texture analyzer (Texture Technologies Corporation, Scarsdale, NY) using a $500 \mathrm{~N}$ load cell with a flat plunger.

\section{Proteolysis}

Samples of cheese were taken after 7, 21, and 28 $\mathrm{d}$ of storage and frozen at $-20^{\circ} \mathrm{C}$ until analyzed for proteolysis. Water-soluble fractions of the cheeses were prepared according to the method of Kuchroo and Fox (1982), and the extract was analyzed for $\mathrm{N}$ by the Kjeldahl method. Primary proteolysis was assessed by performing urea-PAGE of the cheeses and by determining water-soluble $\mathrm{N}$ as percentage of total $\mathrm{N}$. Total free amino acids (an index of secondary proteolysis) were determined by method of Folkerstma and Fox (1992).

\section{Statistical Analysis}

The data collected were statistically analyzed by ANOVA (one way and general linear model) using Minitab statistical software package for Windows 98 (Minitab Inc, State College, PA).

\section{RESULTS AND DISCUSSION}

\section{Composition of Milk}

The standardized milk for vats 2 and 3 had significantly higher fat, protein, and TS contents than those for vat 1 (Table 1 ).

\section{Cheese Yield}

The yield of pizza cheese made by culture acidification from WM plus SM (vat 1) was $10.34 \%$ compared with $14.51 \%$ in that made from WM plus MPC mixture (vat 2) (Table 2), suggesting that standardization of whole milk by MPC results in higher cheese yields. The yield of cheese made from standardized milk (WM + MPC) by direct acidification (vat 3) was $16.65 \%$ compared with $14.51 \%$ for that made by culture acidification (vat 2). The higher yield obtained in vat 3 than in vat 2 was due to the higher moisture content in vat 3 cheese than in the vat 2 cheese (Table 3 ). The $50 \%$ moisture adjusted yields were 11.19, 15.37, and $15.45 \%$ in vats 1,2 , and 3 cheeses, respectively.

The percentage of fat and protein recoveries among vats were insignificant; however, significant differences $(P<0.01)$ were observed in the TS recoveries (Table 1). The cheeses made from standardized milk containing MPC had significantly higher TS recoveries than those made from WM plus SM. Demott (1982) reported an average fat recovery of $84.31 \%$ in Mozzarella cheese manufactured by direct acidification from fluid milk or from reconstituted NFDM and cream but found that protein and TS recoveries in cheese made from NFDM plus cream by direct acidification were higher than in that made from fluid milk.

\section{Composition of Cheese}

Except for protein, the concentrations of all the other cheese components were significantly different be- 
Table 1. Composition ${ }^{1}( \pm \mathrm{SD})$ of standardized milk used for pizza cheese manufacture.

\begin{tabular}{llll}
\hline Vat $^{2}$ & Fat $(\%)$ & Protein $(\%)$ & Total solids $(\%)$ \\
\hline 1 & $2.70 \pm 0.30$ & $3.77 \pm 0.38$ & $11.42 \pm 0.21$ \\
2 & $3.60 \pm 0.60$ & $5.08 \pm 0.59$ & $13.44 \pm 0.29$ \\
3 & $3.60 \pm 0.08$ & $5.02 \pm 0.53$ & $13.44 \pm 0.29$ \\
$P$-value & 0.005 & 0.001 & 0.000 \\
\hline
\end{tabular}

\footnotetext{
${ }^{1}$ Mean of three trials analyzed in duplicate.

${ }^{2}$ Vat $1=$ whole milk plus skim milk; culture acidification; vat $2=$ whole milk plus milk protein concentrate; culture acidification; vat $3=$ whole milk plus milk protein concentrate; direct acidification.
}

tween vats 1,2 , and 3 (Table 3 ). The calcium content was significantly higher in the culture-acidified cheeses made from WM plus MPC than that made from WM plus SM, suggesting that addition of MPC to WM results in higher calcium content in the resultant pizza cheese. The higher calcium content in the MPC containing cheese is good from the nutritional point of view but resulted in lower meltability during storage (Figure 1). The cheese made by using direct acidification from WM plus MPC had the lowest calcium concentration and best initial melt. The reduction in the calcium contents in cheese made by direct acidification technique is due to lower $\mathrm{pH}$ of the standardized milk. As the $\mathrm{pH}$ of standardized milk is reduced, colloidal calcium gets converted to soluble calcium and subsequently gets lost in whey (Kiely et al., 1992). The reduction in calcium contents by direct acidification are in agreement with those of Joshi et al. (2002) who lowered the calcium content of part-skim Mozzarella cheese by preacidifying milk with citric acid.

Pizza cheese made by culture acidification of WM plus MPC had lower lactose content than that made from WM plus SM. The reduced lactose content will help to minimize the browning defect during baking of cheese on pizza. The cheese made by direct acidification technique had $0.53 \%$ lactose compared to 0.33 and $0.32 \%$, respectively, in the cheeses made by culture acidification from WM plus SM and from WM plus MPC. The utilization of lactose by culture microorgan- isms during manufacture resulted in lower lactose contents in the cheeses made by culture acidification compared with the cheese made by direct acidification technique. The concentration of $\beta$-galactose (a byproduct of lactose fermentation by $S$. thermophilus) was minimum in the cheese manufactured by direct acidification. The cheese made by culture acidification technique from MPC plus WM had slightly lower $\beta$-galactose content than that made from WM plus SM, suggesting faster activity of starter bacteria in the cheese made from WM plus SM compared with that made from MPC plus WM. The high protein content in vat 2 cheese due to addition of MPC resulted in higher buffering capacity compared with vat 1 , hence, lower finished $\mathrm{pH}$ in vat 1 than in vat 2 cheeses.

\section{Functional Properties}

The pizza cheese made by direct acidification had significantly $(P<0.00)$ higher meltability (Figure 1$)$ during the first $21 \mathrm{~d}$ of storage. However, after $28 \mathrm{~d}$ of storage, the differences in meltability due to treatment became insignificant $(P>0.25)$. The initial high meltability value of cheese made by direct acidification (vat 3) compared with that made by culture acidification is due to its high moisture and low calcium contents (Table 3 ) and also its high degree of primary proteolysis (Figures 2 and 3) compared with vats 1 and 2 cheeses. Joshi et al. (2002) reported that lowering the

Table 2. Percent ${ }^{1}$ yields and fat, protein, and total solid recoveries during pizza cheese manufacture.

\begin{tabular}{llllll}
\hline Vat $^{2}$ & $\begin{array}{l}\text { Actual } \\
\text { yield }\end{array}$ & $\begin{array}{l}50 \% \text { Moisture- } \\
\text { adjusted yield }\end{array}$ & $\begin{array}{l}\text { Fat } \\
\text { recovery } \\
(\%)\end{array}$ & $\begin{array}{l}\text { Protein } \\
\text { recovery } \\
(\%)\end{array}$ & $\begin{array}{l}\text { Total solids } \\
\text { recovery } \\
(\%)^{3}\end{array}$ \\
\hline 1 & 10.34 & 11.19 & 78.19 & 64.13 & 44.30 \\
2 & 14.51 & 15.37 & 86.29 & 61.52 & 55.68 \\
3 & 16.65 & 15.45 & 77.07 & 58.44 & 53.49 \\
SEM & 0.29 & 0.28 & 1.96 & 2.30 & 1.10 \\
$P$-value & 0.00 & 0.00 & 0.146 & 0.611 & 0.002 \\
\hline
\end{tabular}

\footnotetext{
${ }^{1}$ Mean of three trials analyzed in duplicate.

${ }^{2}$ Vat $1=$ whole milk plus skim milk; culture acidification; vat $2=$ whole milk plus milk protein concentrate; culture acidification; vat $3=$ whole milk plus milk protein concentrate; direct acidification.

${ }^{3}$ After subtracting salt contents from the cheeses.
} 
Table 3. Composition ${ }^{1}$ of 7 -d-old pizza cheeses. ${ }^{2}$

\begin{tabular}{lcccccccc}
\hline Vat $^{3}$ & $\begin{array}{l}\text { Moisture } \\
(\%)\end{array}$ & $\begin{array}{l}\mathrm{FDM}^{4} \\
(\%)\end{array}$ & $\begin{array}{l}\text { Protein } \\
(\%)\end{array}$ & Salt $(\%)$ & $\begin{array}{l}\mathrm{Ca}(\mathrm{mg} / 100 \\
\mathrm{g})\end{array}$ & $\begin{array}{l}\text { Lactose } \\
(\%)\end{array}$ & $\begin{array}{l}\beta \text {-Galactose } \\
(\%)\end{array}$ & $\mathrm{pH}$ \\
\hline 1 & 46.18 & 37.92 & 22.59 & 1.42 & 534.1 & 0.33 & 0.14 & 5.38 \\
& $( \pm 1.50)$ & $( \pm 1.49)$ & $( \pm 2.16)$ & $( \pm 0.50)$ & $( \pm 0.01)$ & $( \pm 0.01)$ & $( \pm 0.02)$ & $( \pm 0.02)$ \\
2 & 47.18 & 38.64 & 23.70 & 2.22 & 590.0 & 0.32 & 0.13 & 5.47 \\
& $( \pm 1.17)$ & $( \pm 2.15)$ & $( \pm 1.19)$ & $( \pm 0.46)$ & $( \pm 0.01)$ & $( \pm 0.00)$ & $( \pm 0.01)$ & $( \pm 0.05)$ \\
3 & 53.87 & 34.68 & 23.37 & 2.04 & 342.5 & 0.53 & 0.01 & 5.59 \\
& $( \pm 2.79)$ & $( \pm 1.54)$ & $( \pm 2.26)$ & $( \pm 0.44)$ & $( \pm 0.01)$ & $( \pm 0.01)$ & $( \pm 0.01)$ & $( \pm 0.02)$ \\
$p$-value & 0.000 & 0.001 & 0.605 & 0.025 & 0.009 & 0.033 & 0.000 & 0.000 \\
\hline
\end{tabular}

${ }^{1}$ Mean of three trials analyzed in duplicate.

${ }^{2}$ Numbers in the parenthesis are standard deviations.

${ }^{3}$ Vat 1 = whole milk plus skim milk; culture acidification; vat 2 = whole milk plus milk protein concentrate; culture acidification; vat $3=$ whole milk plus milk protein concentrate; direct acidification.

${ }^{4}$ Fat in DM.

concentration of micellar calcium by preacidification of milk increased melt area of salted and unsalted part-skim Mozzarella cheese. Upadhyay et al. (1986) reported that Mozzarella cheese made from buffalo milk by direct acidification had higher meltability compared with that made using starter culture.

Seven-day-old vats 1 and 2 cheeses had similar rates of meltability, but after $21 \mathrm{~d}$ vat 1 had better meltability, probably due to slightly faster proteolysis in vat 1 compared with vat 2 cheese. Also vat 2 cheese had significantly $(P<0.05)$ higher levels of calcium compared with vat 1 cheese, which may also have contributed to reduced meltability of vat 2 cheese. Paulson et al. (1998) reported that high calcium in cheese results in aggregation of casein, thus more energy is required to disrupt the protein matrix, which leads to poor melting. The meltability progressively increased during storage in the culture-acidified cheeses. Kuo et al. (2001) reported that meltablity of cheeses increased

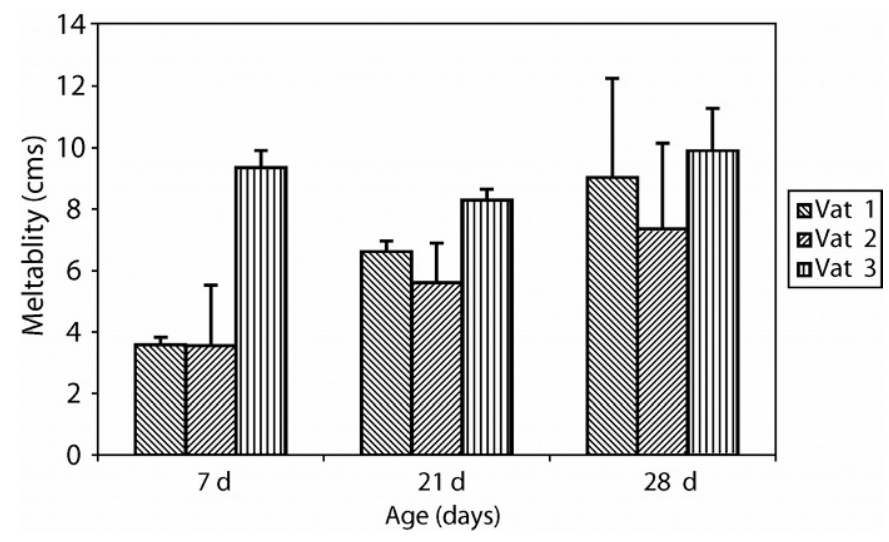

Figure 1. Meltability* $(\mathrm{cm})$ during storage of pizza cheeses heated at $110^{\circ} \mathrm{C}$ for 60 min. Vat $1=$ whole milk plus skim milk; culture acidification; vat $2=$ whole milk plus milk protein concentrate; culture acidification; vat $3=$ whole milk plus milk protein concentrate; direct acidification. * Mean of three trials analyzed in duplicate. during aging due to structural modifications in the cheese during maturation. The meltability of cheese made by direct acidification remained nearly constant during the storage period. The similarities in meltability of cheeses after $28 \mathrm{~d}$ may be due to increases in proteolysis during storage. Joshi et al. (2002) reported that increased proteolysis during storage had a greater influence on melting property than calcium content of cheese.

Little or no browning plus large-sized blisters (Table 4) were observed when vat 3 cheeses were baked on pizza, whereas moderate browning and very smallsized blisters were noted on vat 1 and extensive brown-

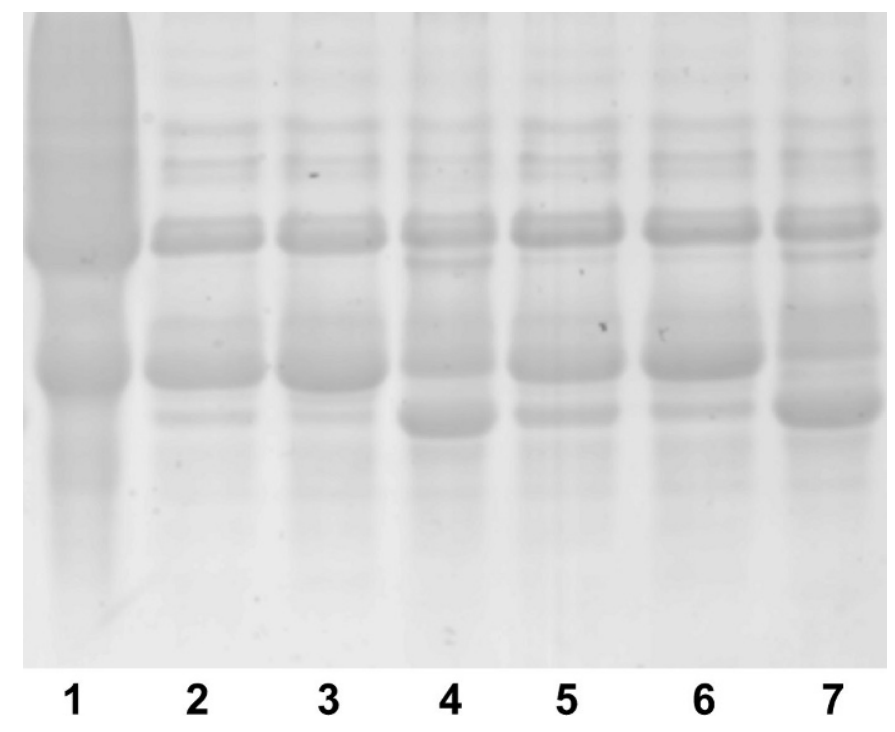

Figure 2. Urea-polyacrylamide gel electrophoresis of pizza cheeses. Lane 1 is sodium caseinate, lanes 2 to 4 are 7-d-old cheeses obtained from vats 1,2 , and 3 , respectively; lanes 5 to 6 are 28-dold vat 1,2 , and 3 cheeses. Vat 1 = whole milk plus skim milk; culture acidification; vat $2=$ whole milk plus milk protein concentrate; culture acidification; vat $3=$ whole milk plus milk protein concentrate; direct acidification. 


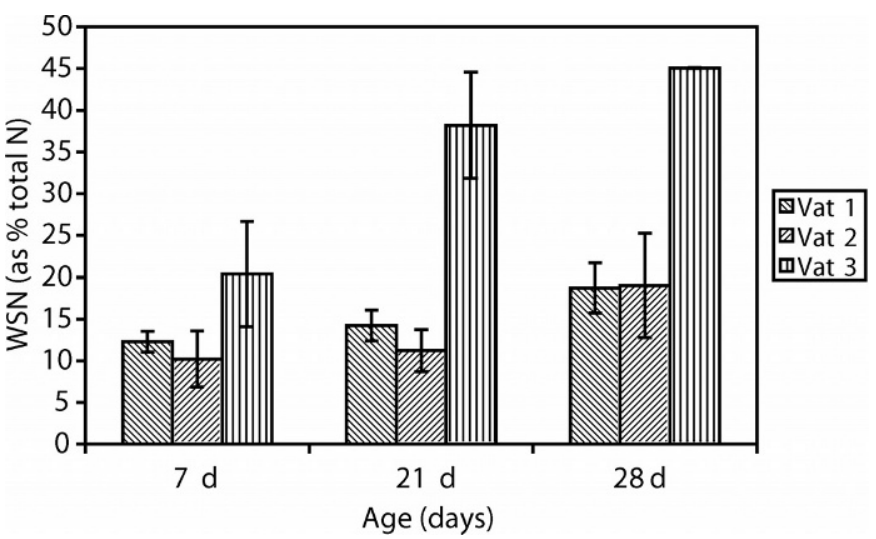

Figure 3. Water-soluble* $\mathrm{N}$ (as percentage of total $\mathrm{N}$ ) content during storage of pizza cheese. Vat $1=$ whole milk plus skim milk; culture acidification; vat $2=$ whole milk plus milk protein concentrate; culture acidification; vat $3=$ whole milk plus milk protein concentrate; direct acidification. *Mean of three trials analyzed in duplicate.

ing and medium-sized blisters in vat 2 cheeses. The little or moderate browning in vat 3 cheeses may be due to reduced concentration of amino acids (secondary proteolysis) (Table 5), although vat 3 cheeses had the highest level of primary proteolysis (Figures 2 and 3). The browning of baked Mozzarella cheese is a result of residual lactose or galactose in the cheese undergoing Maillard browning reaction with peptides and amino acids (Johnson and Olson, 1985). The cheese made by culture acidification contained significantly higher galactose content than that made by direct acidification. Both lactose and galactose are reducing sugars and can react with amino groups and can cause browning. Oberg et al. (1991) reported that Mozzarella cheese made by direct acidification remained white after baking compared with that made with starter cultures and did not brown even though there was considerable amount of residual lactose. The large size blisters observed during the baking of vat 3 cheeses on pizza is due to higher moisture contents (Table 3) in vat 3 cheese compared with vats 1 and 2 cheeses. The blisters in Mozzarella cheese are formed when it is heated to temperatures above $100^{\circ} \mathrm{C}$. The moisture at surface or below the cheese is converted to steam

Table 4. Baking properties in pizza oven at $232^{\circ} \mathrm{C}$ for $3.25 \mathrm{~min}$.

\begin{tabular}{lll}
\hline Vat $^{1}$ & Browning & Size of blisters \\
\hline 1 & Moderate & $0.5 \mathrm{~mm}$ diameter \\
2 & Extensive & $1.0 \mathrm{~mm}$ diameter \\
3 & Little to moderate & $2.0 \mathrm{~mm}$ diameter \\
\hline
\end{tabular}

${ }^{1}$ Vat 1 = whole milk plus skim milk; culture acidification; vat $2=$ whole milk plus milk protein concentrate; culture acidification; vat 3 = whole milk plus milk protein concentrate; direct acidification. and the trapped air between the molten cheese and toppings collect in bubbles under the molten surface. Next the cheese surface over these bubbles begins to rise from the expansion of trapped air and steam, initiating the formation of a blister (Rudan and Barbano, 1998).

\section{Proteolysis}

Urea-PAGE of the cheeses (Figure 2) and their water-soluble $\mathrm{N}$ contents (Figure 3 ) showed that vat 3 cheeses had higher levels of proteolysis compared with vats 1 and 2 cheeses. The higher level of proteolysis found in vat 3 cheeses may be due to lower $\left(36^{\circ} \mathrm{C}\right)$ curd cooking temperature used during the manufacture of vat 3 cheeses compared with cooking temperature of $46^{\circ} \mathrm{C}$ in vats 1 and 3 cheeses. Yun et al. (1993) used three cooking temperatures $\left(38,41\right.$, and $\left.44^{\circ} \mathrm{C}\right)$ during the manufacture of Mozzarella cheese and found that as cooking temperature increased, proteolysis decreased. Chymosin is inactivated at temperatures $>45^{\circ} \mathrm{C}$ (Fox and McSweeney, 1997). Also, because of the low $\mathrm{pH}$ at setting, the level of coagulant retained was high as residual coagulant increases with the $\mathrm{pH}$ of the milk at clotting decreases (Farkye, 1995). Ernstrom (1987) reported that more coagulant gets attached with cheese curd when manufactured from preacidified milk and results in higher proteolysis. Vat 3 cheese had lower calcium compared with vats 1 and 2.

Joshi et al. (2002) reported that rate of proteolysis in cheeses containing low concentrations of $\mathrm{Ca}$ was higher than in cheese containing high levels of calcium. Dave et al. (2003) reported that residual chymosin and plasmin are responsible for breaking down $\alpha_{\mathrm{s} 1}-\mathrm{CN}$ and $\beta$-CN in Mozzarella cheese (made by direct acidification) during storage. Plasmin has been reported to cause initial hydrolysis of $\beta$-CN (and $\alpha_{\mathrm{s} 1^{-}}$ $\mathrm{CN}$ ) due to its greater specificity towards $\beta$-CN, when chymosin is used as a coagulant (Benfeldt et al., 1997). Plasmin inhibitors get inactivated at temperatures be-

Table 5. Concentration ${ }^{1}( \pm$ SD) of free amino acids (mg Leu/g of cheese) during storage of pizza cheese.

\begin{tabular}{llll}
\hline & \multicolumn{3}{c}{ Age of cheese (days) } \\
\cline { 2 - 4 } Vat $^{2}$ & 7 & 21 & 28 \\
\hline 1 & $0.310 \pm 0.030$ & $0.354 \pm 0.002$ & $0.484 \pm 0.001$ \\
2 & $0.296 \pm 0.030$ & $0.395 \pm 0.001$ & $0.451 \pm 0.025$ \\
3 & $0.230 \pm 0.050$ & $0.300 \pm 0.003$ & $0.316 \pm 0.005$ \\
$P$-value & 0.008 & 0.000 & 0.000 \\
\hline
\end{tabular}

${ }^{1}$ Mean of three trials analyzed in triplicate.

${ }^{2}$ Vat 1 = whole milk plus skim milk; culture acidification; vat $2=$ whole milk plus milk protein concentrate; culture acidification; vat $3=$ whole milk plus milk protein concentrate; direct acidification. 
Table 6. Force $(g)$ required to compress 50 or $70 \%$ height of 7-d-old pizza cheese sample.

\begin{tabular}{lcc}
\hline Vat $^{1}$ & $50 \%$ Compression & $70 \%$ Compression \\
\hline 1 & $4229 \pm 607$ & $6638 \pm 334$ \\
2 & $6818 \pm 979$ & $14773 \pm 1286$ \\
3 & $930 \pm 13.5$ & $3941 \pm 132$ \\
\hline
\end{tabular}

${ }^{1}$ Vat 1 = whole milk plus skim milk; culture acidification; vat $2=$ whole milk plus milk protein concentrate; culture acidification; vat $3=$ whole milk plus milk protein concentrate; direct acidification.

tween 63 to $90^{\circ} \mathrm{C}$, whereas plasmin is a relatively heat stable enzyme. Farkye et al. (1991) reported that considerable proteolysis in Mozzarella cheese occurs in $14 \mathrm{~d}$ of refrigerated storage, soluble $\mathrm{N}$ increases from $4 \%$ of total $\mathrm{N}$ to $10 \%$ after $14 \mathrm{~d}$. The concentration of free amino acids was higher in the culture acidified cheeses compared with those made by direct acidification (Table 5), probably due to activities of starter peptidases.

\section{Hardness}

The force required to compress 50 or $70 \%$ height of 7-d-old cheese samples showed that vats 3 and 2 cheeses had the softest body texture and hardest textures, respectively (Table 6 ). The soft texture in vat 3 cheese may be due to more moisture, less calcium, and higher level of proteolysis compared with vats 2 and 3 cheese. These results are in agreement with those of Metzger et al. (2001) who reported the least hardness in low-fat Mozzarella cheese due to preacidification of milk. Vat 2 cheese had the highest calcium content, making it possibly the hardest cheese. Bhaskaracharya and Shah (1999) reported that increase in moisture content of Mozzarella cheese resulted in decreased hardness.

\section{CONCLUSIONS}

The use of MPC in pizza cheese manufacture increased yields regardless of whether cheese was made by culture or direct acidification. Also, the use of MPC resulted in increased calcium content in the cheeses made by culture acidification but low calcium in cheeses made by direct acidification. Cheeses made by direct acidification gave high melt and minimum browning when used for pizza baking immediately after manufacture and during storage. Pizza cheese made from MPC and by culture acidification improved meltability during storage. A Lactobacillus helveticus strain capable of readily fermenting galactose may be included in the starter culture if pizza cheese from MPC with minimum browning is to be obtained.

\section{ACKNOWLEDGMENTS}

The financial support of Dairy Management, Inc. and California Dairy Research Foundation is greatly acknowledged. The help of Theresse Considine, Jerry Mattas in cheese making, and that of Sean Vink in texture analysis is appreciated.

\section{REFERENCES}

Association of Official Analytical Chemists. 1990. Official Methods of Analysis. 16th ed. AOAC, Arlington, VA.

Benfeldt, C., J. Sorensen, K. H. Ellegard and T. E. Peterson. 1997. Heat-treatment of cheese milk: effect on plasmin activity and proteolysis during cheese ripening. Int. Dairy J. 7:723-731.

Bhaskararacharya, R. K., and N. P. Shah. 1999. Texture evaluation of commercial Mozzarella cheese. Aust. J. Dairy Technol. 54: $36-40$.

Bhaskararacharya, R. K., and N. P. Shah. 2000. Texture characteristics and microstructure of skim milk Mozzarella cheese using exopolysaccharide producing starter cultures. Aust. J. Dairy Technol. 55:132-138.

Dave, R. I., D. J. McMahon, C. J. Oberg, and J. R. Broadbent. 2003. Influence of coagulant level on proteolysis and functionality of Mozzarella cheese made using direct acidification. J. Dairy Sci. $86: 114-126$

Demott, B. J. 1982. Recovery of milk constituents in a Mozzarellalike product manufactured from non-fat dry milk and cream by direct acidification at 4 and $35^{\circ} \mathrm{C}$. J Dairy Sci. 66:2501-2506.

Ernstrom, C. A. 1987. Residual milk clotting enzymes in curd. Pages 1-9 in Proc. 23rd Annual Marshall Italian Cheese Seminar. Madison, WI.

Farkye, N. Y. 1995. Contribution of milk clotting enzymes and plasmin to cheese ripening. Pages 195-207 in Chemistry of Structure-Function Relationship in Cheese. E. L. Malin and M. H. Tunick, eds. Plenum Press, New York.

Farkye, N. Y., L. J. Kiely, R. D. Allhouse, and P. S. Kindstedt. 1991. Proteolysis in Mozzarella cheese during refrigerated storage. J. Dairy Sci. 74:1433-1438.

Folkertsma, B., and P. F. Fox. 1992. Use of the Cd-ninhydrin reagent to assess proteolysis in cheese during ripening. J. Dairy Res. 59:217-224

Fox, P. F., and P. L. H. McSweeney. 1997. Rennets: Their role in milk coagulation and cheese ripening. Pages 1-49 in Microbiology and Biochemistry of Cheese and Fermented Milk. 2nd ed. B. A. Law, ed. Elsevier Applied Science Publishers, London.

Johnson, M. E., and N. F. Olson. 1985. Non-enzymatic browning of Mozzarella cheese. J. Dairy Sc. 68:3143-3147.

Joshi, N. S., K. Muthukumerappan, and R. I. Dave. 2002. Role of soluble and colloidal calcium on functionality of salted and unsalted part-skim Mozzarella cheese. Aust. J. Dairy Technol. 57:203-210.

Keily, L. J., P. S. Kindstedt, G. M. Hendrick, J. E. Levis, J. J. Yun, and D. M. Barbano. 1992. Effect of draw $\mathrm{pH}$ on the development of curd structure during manufacture of Mozzarella cheese. Food Struc. 11:217-224.

Kuchroo, C. N., and P. F. Fox. 1982. Soluble nitrogen in Cheddar cheese: comparison of extraction procedures. Milchwissenschaft 37:331-335.

Kuo, M. I., and Y. C. Wang. 2001. Effect of heat treatments on the meltability of cheeses. J. Dairy Sci. 84:1937-1943.

Marshall, T. R., ed. 1992. Standard Methods for the Examination of Dairy Products. 15th ed. Am. Publ. Health Assoc., Inc., Washington, DC.

McMahon, D. J., C. J. Oberg, and W. McManus. 1993. Functionality of Mozzarella cheese. Aust. J. Dairy Technol. 48:99-104.

Metzger, L. E., D. M. Barbano, P. S. Kindstedt, and M. R. Guo. 2001. Effect of milk preacidification on low-fat Mozzarella cheese. II. 
Chemical and functional properties during storage. J. Dairy Sci. 84:1348-1356.

Oberg, C. J., A. Wang, L. V. Moyes, R. J. Brown, and G. H. Richardson. 1991. Effects of thermolactic culture proteolytic activity on physical properties of Mozzarella cheese. J. Dairy Sci. 74:389397.

Olson, N. F., and W. V. Price. 1958. A melting test for pasteurized process cheese spreads. J. Dairy Sci., 41:999.

Paulson, B. M., D. J. McMahon, and C. J. Oberg. 1998. Influence of sodium chloride on appearance, functionality and protein arrangements in non-fat Mozzarella cheese. J. Dairy Sci. 81:2053-2064.

Pederson, P. J., and N. K. Ottoson. 1992. Manufacture of fresh cheese by ultrafiltration: New application of membrane process. IDF special issue. 9201. IDF, Brussels, Belgium.
Rudan, M. A., and D. M. Barbano. 1998. A model of Mozzarella cheese melting and browning during pizza baking. J. Dairy Sci. 81:2312-2319.

Shakeel-Ur-Rehman, N. Y. Farkye, and M. A. Drake. 2003. Reducedfat Cheddar cheese from a mixture of cream and liquid milk protein concentrate. Int. J. Dairy Technol. 56:94-98.

Shakeel-Ur-Rehman, N. Y. Farkye, T. Considine, A. Schaffner, and M. A. Drake. 2003. Effects of standardization of whole milk with dry milk protein concentrate on the yield and ripening of reduced-fat Cheddar cheese. J. Dairy Sci. 86:1608-1615.

Upadhyay, K. G., G. C. Patel, M. N. Vaghela, and M. R. Sunder. 1986. Manufacture of Mozzarella cheese from buffalo milk. Indian Dairyman 38:479-486.

Yun, J. J., L. J. Kiely, D. M. Barbano, and P. S. Kinstedt. 1993. Mozzarella cheese: Impact of cooking temperature on chemical composition, proteolysis and functional properties. J. Dairy Sci. 76:3664-3673. 